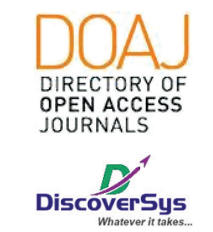

Published by DiscoverSys

\section{Gambaran kepatuhan terapi antiretroviral pada lelaki-seks-lelaki di Klinik Bali Medika}

\author{
Phebe Indriani, ${ }^{1 *}$ Putu Cintya Denny Yuliyatni, ${ }^{2}$ Luh Seri Ani, ${ }^{2}$ I Wayan Weta ${ }^{2}$
}

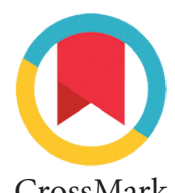

CrossMark

\section{ABSTRACT}

Background: HIV prevalence in Indonesia and Bali is quite large. The main factor in achieving success in the treatment of HIV / AIDS virus infections is compliance.

Aim: This study aims to determine the adherence of ARV therapy to MSM based on the characteristics and clinical stage in one of the CST clinics, the Bali Medika clinic. This descriptive study with cross sectional design used simple random sampling from the register of HIV patients at the Bali Medika Clinic so as to get 90 MSM (male-sex-male) patients. Data sources were taken from medical records regarding the characteristics, clinical stage, and treatment compliance of the study subjects. The data obtained were analyzed and displayed in the form of frequency tables and cross tables.

Results: The majority of MSM sufferers with HIV are less than 31 years old; single (95.6\%); low education (52.2\%); have a job (94.4\%); are in clinical stage I (77.8\%); do not have coinfection (86.7\%); use FDC drugs (92.2\%); and suffered side effects from dizziness (90.0\%). Most $(66.7 \%)$ adhere to the Bali Medika Clinic.

Conclusion: MSM at the Bali Medika Clinic tend to have high compliance in carrying out ARV therapy.

Keywords: HIV, ARV, Adherence to Therapy, MSM

Cite This Article: Indriani, P., Yuliyatni, P.C.D., Ani, L.S., Weta, I.W. 2020. Gambaran kepatuhan terapi antiretroviral pada lelaki-seks-lelaki di Klinik Bali Medika. Intisari Sains Medis 11(2): 535-539. D0I: 10.15562/ism.v11i2.664

ABSTRAK

Latar Belakang: Prevalensi HIV di Indonesia dan Bali cukup besar. Faktor utama dalam mencapai keberhasilan pengobatan infeksi virus HIV/AIDS adalah kepatuhan.

Tujuan: Penelitian ini bertujuan untuk mengetahui kepatuhan terapi ARV pada LSL (lelaki-seks-lekali) berdasarkan karakteristik dan stadium klinis di salah satu klinik CST, yaitu klinik Bali Medika.

Metode: Desain penelitian dengan rancangan potong lintang ini menggunakan simple random sampling dari daftar register pasien HIV di Klinik Bali Medika sehingga mendapatkan 90 pasien LSL. Sumber data diambil dari rekam medis mengenai karakteristik, stadium klinis, dan kepatuhan terapi dari subjek penelitian. Data yang diperoleh dianalisis dan ditampilkan dalam bentuk tabel frekuensi dan tabel silang.

Hasil: Sebagian besar LSL penderita HIV berusia kurang dari sama dengan 31 tahun; belum menikah (95,6\%); berpendidikan rendah (52,2\%); memiliki pekerjaan $(94,4 \%)$; berada dalam stadium klinis I (77,8\%); tidak memiliki koinfeksi (86,7\%); menggunakan jenis obat FDC (92,2\%); dan menderita efek samping pusing $(90,0 \%)$. Sebagian besar $(66,7 \%)$ patuh berkunjung ke Klinik Bali Medika.

Simpulan: LSL di Klinik Bali Medika cenderung memiliki kepatuhan yang tinggi dalam menjalankan terapi ARV.
1Program Studi Sarjana Kedokteran dan Profesi Dokter, Fakultas Kedokteran, Universitas Udayana, Denpasar, Bali

${ }^{2}$ Departemen Kedokteran Masyarakat dan Kedokteran Perorangan, Fakultas Kedokteran, Universitas Udayana, Denpasar, Bali

*Correspondence to: Phebe Indriani, Program Studi Sarjana Kedokteran dan Profesi Dokter, Fakultas Kedokteran, Universitas Udayana, Denpasar, Bali phebe10ind@yahoo.com

Diterima: 15-11-2019

Disetujui: 09-07-2020

Diterbitkan: 01-08-2020
Kata Kunci: HIV, ARV, Kepatuhan Terapi, LSL

Cite Pasal Ini: Indriani, P., Yuliyatni, P.C.D., Ani, L.S., Weta, I.W. 2020. Gambaran kepatuhan terapi antiretroviral pada lelaki-seks-lelaki di Klinik Bali Medika. Intisari Sains Medis 11(2): 535-539. D0I: 10.15562/ism.v11i2.664

\section{PENDAHULUAN}

Berdasarkan WHO (World Health Organization), jumlah penderita HIV di seluruh dunia pada tahun 2013 terdapat 35 juta orang. Pada tahun 2013 jumlah infeksi baru HIV/AIDS sebanyak 2,1 juta orang. Jumlah kematian akibat AIDS sebanyak 1,5 juta orang. Salah satu negara dengan tingkat penderita HIV/AIDS yang tinggi adalah Indonesia. HIV sudah menyebar ke 507 kabupaten/kota di seluruh provinsi di Indonesia. Jumlah penderita HIV/AIDS di Indonesia sebanyak 242.699 orang dan akan menjadi satu juta orang dalam 10 tahun jika tidak dilakukan penanganan yang serius dan didukung semua pihak. Berdasarkan Kemenkes RI tahun 2017, di provinsi Bali ditemukan kasus HIV/AIDS pertama kali pada tahun 1987 dan terus menunjukan peningkatan dari tahun ke tahun. Insidensi infeksi HIV/AIDS terutama pada kelompok umur 25-49 tahun, kemudian diikuti umur 20-24 tahun. Selain itu, penularan HIV/AIDS berdasarkan jenis kelamin lebih banyak terjadi pada pria (54\%) 
dibanding wanita (29\%). Pola penularan HIV/ AIDS berdasarkan faktor risiko pada tahun 2017 yaitu lebih dominan terjadi pada Lelaki Seks Lelaki sebesar 28\%, heteroseksual sebesar 24\%, lain-lain sebesar 9\%, dan penggunaan jarum suntuk tidak steril pada penasun sebesar $2 \%{ }^{1}$

Saat ini pengobatan terbaik untuk penderita HIV adalah antiretroviral (ARV). Cara kerja obat ARV ini adalah dengan mengurangi jumlah virus sehingga dapat meningkatkan status imun dari penderita, jika status imun pasien meningkat maka akan mengurangi infeksi oportunistik dan mengurangi tingkat kematian. ARV ini sudah dikonsumsi oleh $46 \%$ penderita HIV di seluruh dunia berdasarkan data WHO tahun 2015. Jumlah kematian pada penderita HIV yang menggunakan ARV sudah menurun dari tahun 2010 sampai 2015 dari angka 1,5 juta menjadi 1,1 juta. Dengan berkurangnya angka kematian, maka prevalensi penderita HIV akan semakin tinggi secara kumulatif. Obat ARV sudah disediakan secara gratis melalui program pemerintah Indonesia sejak tahun 2014 dan kini sudah tersedia di lebih dari 400 layanan kesehatan seluruh Indonesia.

Faktor utama dalam keberhasilan suatu pengobatan terhadap infeksi virus HIV merupakan kepatuhan. Kepatuhan (adherence) adalah suatu bentuk perilaku dalam mengkonsumsi obat secara tepat waktu dengan dosis yang sesuai dan tidak pernah lupa. ${ }^{2}$ Dari sebuah penelitian didapatkan bahwa faktor penyebab kegagalan dari pengobatan HIV adalah kepatuhan mengkonsumsi obat ARV dibawah 80\%. (Haubrich,1999). Terdapat banyak faktor yang berpengaruh dalam mengkonsumsi obat, diantaranya yaitu: tingkat pendidikan, jenis kelamin, interaksi obat, stigma, sosial ekonomi, efek samping obat, dan pill burden. Terdapat juga penyebab lain yaitu pasien jenuh dan merasa penyakitnya tidak akan sembuh, kecemasan atau depresi, komunikasi antara penderita HIV dan petugas kesehatan yang kurang baik, konsumsi alkohol, penyalahgunaan obat - obatan, dan sebagainya. ${ }^{3}$ Berdasarkan data dari WHO didapatkan bahwa intervensi kepatuhan terhadap antiretroviral menyebabkan penurunan jumlah virus sebanyak $70 \%{ }^{2}$

Di Bali terdapat Klinik Bali Medika yang berperan sebagai klinik kesehatan dan komunitas bagi LSL. Klinik Bali Medika berdiri sejak Oktober 2011. ${ }^{4}$ Klinik tersebut memberikan pelayanan pengecekan status HIV dan IMS pada LSL. Selain itu LSL diberikan kemudahan untuk melakukan konseling baik sebelum ataupun sesudah menjalani test HIV. Klinik Bali Medika juga memberikan informasi mengenai HIV, komplikasi HIV melalui sosial media. Klinik Bali Medika juga menyediakan ARV yang secara rutin diambil bagi pasien LSL penderita HIV positif. Kehadiran klinik dan komunitas ini membuat LSL dapat saling memberikan dukungan dan berbagi informasi. Melalui hal tersebut diharapkan infeksi HIV pada LSL di Bali mendapat pelayanan kesehatan yang semestinya. ${ }^{5}$

\section{METODE}

Jenis penelitian ini adalah deskriptif dengan rancangan potong lintang di amna sampling dilakukan bersamaan pada satu waktu menggunakan rekam medis. Populasi target pada studi ini adalah laki-laki dan berstatus positif HIV yang menjadi pasien di klinik Bali Medika, Badung Bali. Populasi sampel yang digunakan dalam penelitian ini adalah LSL positif HIV di Klinik Bali Medika, Badung, Bali Januari - Juni 2019. Kriteria inklusi adalah LSL positif HIV yang terdata dalam rekam medis secara lengkap di Klinik Bali Medika periode Januari 2019 - Juni 2019. Rekam medis tersebut memuat data mengenai usia, pendidikan, pekerjaan, status pernikahan, stadium klinis, koinfeksi, jenis obat, efek samping, dan kepatuhan terapi ARV. Kriteria eksklusi adalah data rekam medis pasien LSL positif HIV di Klinik Bali Medika periode Januari 2019 - Juni 2019 yang tidak lengkap (tidak mencantumkan data mengenai usia, pendidikan, pekerjaan, status pernikahan, stadium klinis, koinfeksi, jenis obat, efek samping, dan kepatuhan terapi ARV).

Penelitian ini menggunakan data sekunder. Datadata mencakup usia, pendidikan, pekerjaan, status pernikahan, stadium klinis, koinfeksi, jenis obat, efek samping, dan kepatuhan terapi ARV. Sebelum data di masukkan ke dalam format komputer, pengeditan dilakukan guna mengidentifikasi variabel yang belum diberi kode. Data yang telah dikumpulkan akan dilakukan analisis menggunakan program komputer. Data yang telah dianalisa digunakan untuk mengetahui gambaran tingkat kepatuhan terapi ARV pada LSL positif HIV di Klinik Bali Medika. Penyajian data-data tersebut dapat berupa tabel dan narasi. Penelitian ini telah laik dengan nomor surat 905/UN.14.2.2.VII.14/LP/2019 yang dikeluarkan oleh Komisi Etik Penelitian Fakultas Kedokteran Universitas Udayana.

\section{HASIL DAN DISKUSI}

Pada penelitian ini ditemukan kepatuhan penderita HIV sebesar $66,7 \%$. Temuan ini lebih rendah dibandingkan dengan beberapa penelitian sebelumnya. Penelitian di India tahun 2005 menemukan 74,3\% kelompok patuh pada ARV. ${ }^{6}$ Penelitian lain, dilaksanakan pada 2012, menemukan hasil serupa. Penelitian yang dilakukan di Afrika ini menemukan bahwa sebagian besar sampel memiliki kepatuhan pengobatan ARV lebih dari 80\%. ${ }^{7}$ Sementara itu, studi lain di rumah sakit di Ethiopia mendapatkan 
Tabel 1 Karakteristik demografi sampel penelitian

\begin{tabular}{lcc}
\hline Variabel & N & $\%$ \\
\hline Umur, rerata \pm SD & $31,93 \pm 6,67$ tahun & \\
Kelompok Umur & & \\
$\leq 31$ tahun & 48 & 53,3 \\
$>31$ tahun & 42 & 46,7 \\
Status Pernikahan & & \\
Sudah menikah & 4 & 4,4 \\
$\quad$ Belum menikah & 86 & 95,6 \\
Pendidikan & & \\
Rendah & 47 & 52,2 \\
Tinggi & 43 & 47,8 \\
Pekerjaan & & \\
Bekerja & 85 & 54,4 \\
Tidak bekerja & 5 & 100 \\
Total & 90 & \\
\hline
\end{tabular}

Tabel 2 Karakteristik klinis sampel

\begin{tabular}{lcc}
\hline Variabel & N & $\%$ \\
\hline Stadium klinis WHO & 70 & 77,8 \\
I & 6 & 6,7 \\
II & 10 & 11,1 \\
III & 4 & 4,4 \\
IV & & \\
Koinfeksi & 12 & 13,3 \\
Ada & 4 & 4,4 \\
Candidiasis oris & 4 & 4,4 \\
TBC & 2 & 2,2 \\
Herpes & 1 & 1,1 \\
Hepatitis A & 1 & 1,1 \\
Sifilis & 78 & 86,7 \\
Tidak ada & & \\
Jenis obat & 83 & 92,2 \\
FDC & 7 & 7,8 \\
Non-FDC & & 90,0 \\
Efek samping ARV & 90 & 100 \\
Pusing & 9 & \\
SJS & & \\
Total & & \\
\hline
\end{tabular}

Tabel 3 Proporsi kepatuhan berkunjung ke layanan arv

\begin{tabular}{lcc}
\hline Variabel & $\mathbf{N}$ & $\%$ \\
\hline Kepatuhan, rerata \pm SD & $96,56 \% \pm 8,82 \%$ & \\
Kategori kepatuhan & & \\
$\quad$ Tidak Patuh & 30 & 33,3 \\
Patuh & 60 & 66,7 \\
\hline
\end{tabular}

proporsi kepatuhan penderita HIV dalam mengkonsumsi ARV mencapai $93,8 \%{ }^{8}$

Penderita HIV/AIDS yang patuh mengkonsumsi ARV lebih banyak dijumpai pada kelompok dengan pendidikan yang tinggi yaitu $67,4 \%$ seperti yang telah dijabarkan dalam Tabel 1. Hasil ini sejalan dengan temuan studi terdahulu, didapatkan kepatuhan mencapai $77,45 \%$ dari penderita HIV berpendidikan tinggi. ${ }^{9}$ Hal didukung juga oleh penelitian pendahulu yang menemukan bahwa kepatuhan penderita HIV/AIDS dalam mengonsumsi ARV 20 kali lebih tinggi pada tingkat pendidikan yang lebih tinggi. ${ }^{10}$

Penelitian ini menemukan bahwa proporsi tertinggi kepatuhan ditemukan dengan status sudah menikah yaitu 75\%. Hal ini sesuai dengan penelitian sebelumnya yang menemukan bahwa proporsi kepatuhan tertinggi dengan status sudah menikah sebesar 76,9\%. Status pernikahan merupakan salah satu penyebab ketidakpatuhan terhadap pengobatan ARV. ${ }^{11}$

Pada penelitian ini tidak terdapat perbedaan mencolok karakteristik koinfeksi antar kelompok sampel yang patuh dan tidak patuh (Tabel 3 dan 4). Berdasarkan jenis obat, sebagian 67,5\% kelompok yang patuh menggunakan obat FDC. Hal ini sesuai dengan studi bahwa kepatuhan dengan obat FDC mencapai 51\%. ${ }^{12}$ Data dalam studi ini sesuai dengan data yang didapat dari penelitian sebelumnya yang menemukan bahwa dikarenakan alasan penggunaan FDC lebih mudah dengan dosis 1x1 sehingga mengurangi potensi lupa dan akan mempengaruhi kepatuhan dari ODHA. ${ }^{13}$ Data penelitian pada studi ini sesuai dengan studi yang didapat oleh Koole yang dilaksanakan di Tanzania, Uganda dan Zambadia, yang menjelaskan bahwa bentuk obat, jumlah obat dan frekuensi minum obat merupakan beberapa alasan untuk tidak minum obat (Tabel 5). ${ }^{14}$

Berdasarkan efek samping, penderita HIV/ AIDS yang mengalami efek samping terbanyak adalah pusing sebesar $71,6 \%$. Hasil ini sesuai dengan studi terdahulu yang mengatakan bahwa penderita HIV/AIDS paling sering menderita efek samping pusing sebesar $65,5 \% .{ }^{15}$ Berdasarkan hasil penelitian ini, 83,3\% penderita HIV/AIDS berada dalam stadium klinis II. Pada studi tersebut ditemukan bahwa penderita HIV/AIDS dengan kepatuhan tertinggi berada dalam stadium klinis IV sebesar 20,9\%. Perbedaan hasil ini dimungkinkan karena terdapat perbedaan jumlah sampel yang dikumpulkan, dan kondisi awal stadium dari penderita HIV/AIDS. Penelitian tersebut menggunakan 201 sampel dan kebanyakan sampel yang digunakan dalam penelitian ini berobat ketika sakitnya sudah parah atau berada pada stadium IV sebesar $41,8 \% .^{15,16}$ 
Tabel 4 Sebaran kepatuhan ARV berdasarkan karakteristik sampel

\begin{tabular}{|c|c|c|c|}
\hline \multirow[b]{2}{*}{ Variabel } & \multicolumn{2}{|c|}{ Kepatuhan, n (\%) } & \multirow[b]{2}{*}{ Total } \\
\hline & Patuh & Tidak Patuh & \\
\hline \multicolumn{4}{|l|}{ Kelompok Umur } \\
\hline$\leq 31$ tahun & $30(62,5)$ & $18(37,5)$ & $48(100)$ \\
\hline$>31$ tahun & $30(71,4)$ & $12(28,6)$ & $42(100)$ \\
\hline \multicolumn{4}{|l|}{ Status Pernikahan } \\
\hline Menikah & $3(75,0)$ & $1(25,0)$ & $4(100)$ \\
\hline Belum menikah & $57(66,3)$ & $29(33,7)$ & $86(100)$ \\
\hline \multicolumn{4}{|l|}{ Pendidikan } \\
\hline Rendah & $31(66,0)$ & $16(34,0)$ & $47(100)$ \\
\hline Tinggi & $29(67,4)$ & $14(32,6)$ & $43(100)$ \\
\hline \multicolumn{4}{|l|}{ Pekerjaan } \\
\hline Bekerja & $55(64,7)$ & $30(35,3)$ & $85(100)$ \\
\hline Tidak bekerja & $5(100,0)$ & $0(0)$ & $5(100)$ \\
\hline
\end{tabular}

Tabel 5 Sebaran kepatuhan ARV berdasarkan klinis HIV

\begin{tabular}{lccc}
\hline & \multicolumn{2}{c}{ Persentase Kepatuhan, $\mathbf{n}(\%)$} & \\
\cline { 2 - 3 } Variabel & Patuh & Tidak Patuh & Total \\
\hline Stadium klinis WHO & & & \\
I & $47(67,1)$ & $23(32,9)$ & $70(100)$ \\
II & $5(83,3)$ & $1(16,7)$ & $6(100)$ \\
III & $6(60,0)$ & $4(40,0)$ & $10(100)$ \\
IV & $2(50,0)$ & $2(50,0)$ & $4(100)$ \\
Koinfeksi & & & $12(100)$ \\
Ada & $8(66,7)$ & $4(33,3)$ & $78(100)$ \\
Tidak ada & $52(66,7)$ & $26(33,3)$ & \\
Jenis obat & & & $78(100)$ \\
FDC & $56(67,5)$ & $27(32,5)$ & $7(100)$ \\
Non-FDC & $4(57,1)$ & $3(42,9)$ & $78(100)$ \\
Efek samping ARV & & & $9(100)$ \\
Pusing & $58(71,6)$ & $23(28,4)$ & $7(77,8)$ \\
SJS & $2(22,2)$ &
\end{tabular}

Ketidaksesuaian juga ditemukan mengenai kelompok umur dan kepatuhan. Dalam penelitian ini kepatuhan yang lebih tinggi ditemukan pada kelompok umur $>31$ tahun. Pada penelitian sebelumnya ditemukan bahwa sebaran umur yang merata pada kelompok kepatuhan berbeda. Ketidaksesuaian juga ditemukan pada infeksi oportunistik dan kepatuhan. Dalam penelitian ini ditemukan infeksi oportunistik yang sama antara kelompok patuh dan tidak patuh. Penelitian tersebut juga menemukan bahwa infeksi oportunistik terkait dengan ketidakpatuhan menjalani terapi ARV. Oleh karena itu, dapat dikatakan bahwa masih terdapat kontroversi dalam hal ini. ${ }^{17}$

\section{SIMPULAN}

Proporsi penderita HIV/AIDS yang patuh berkunjung ke layanan ARV sekitar 66,7\%. Proporsi penderita HIV yang patuh lebih banyak dijumpai dengan status sudah menikah $71,4 \%$, memiliki pendidikan yang tinggi $67,4 \%$, tidak bekerja $100 \%$, terdapat pada stadium klinis WHO II 83,3\%, menggunakan obat FDC $67,55 \%$, dan memiliki efek samping pusing $71,6 \%$. Kepada pemegang klinik diharapkan agar dapat mempertahankan kepatuhan penderita HIV dalam menjalankan terapi ARV. Kepada pemegang koinik diharapkan agar dapat memberi sosialisasi dan semangat mengenai pentingnya kepatuhan menjalankan terapi ARV untuk usia muda, dengan status belum menikah, berpendidikan rendah, tidak bekerja, stadium klinis IV, menggunakan obat non FDC, dan menderita efek samping SJS. Diharapkan agar dilakukan penelitian lebih lanjut dengan menilai ketepatan minum obat.

\section{KONFLIK KEPENTINGAN}

Tidak ada.

\section{PENDANAAN}

Tidak ada.

\section{DAFTAR PUSTAKA}

1. Kementerian Kesehatan Republik Indonesia. Pedoman pengobatan an retroviral. Jakarta: Kementerian Kesehatan Republik Indonesia; 2015.

2. World Health Organization. Consolidated guideline on the use of an retroviral drugs for treating and preventing HIV infection. 2nd ed. Geneva: World Health Organization; 2016. p.91-154.

3. Chesney MA. Factors affecting adherence to antiretroviral therapy. Clin Infect Dis. 2000;30(Suppl 2):S171-6.

4. Peduli Bali, Peduli Ubud - Ubud Now \& Then [Internet]. Ubud Now \& Then. 2019 [cited 15 January 2019]. Available from: http://ubudnowandthen.com/ peduli-bali-peduli-ubud/

5. Balimedika.com. 2019 [cited 10 January 2019]. Available from: https://www.balimedika.com/wp-content/uploads/ 2017/12/World-Aids-Day-Bali-medika-2016-2017.pdf

6. Safren, S.A., Kumarasamy, N., James, R., Raminani, S., Solomon, S. and Mayer, K.H., 2005. ART adherence, demographic variables and CD4 outcome among HIVpositive patients on antiretroviral therapy in Chennai, India. AIDS care, 17(7), pp.853-862.

7. Lubinga, S.J., Kintu, A., Atuhaire, J. and Asiimwe, S., 2012. Concomitant herbal medicine and Antiretroviral Therapy (ART) use among HIV patients in Western Uganda: a cross-sectional analysis of magnitude and patterns of use, associated factors and impact on ART adherence. AIDS care, 24(11), pp.1375-1383. 
8. Misgaanaa, G. and Malik, T., 2018. Assessment of Adherence to Antiretroviral Therapy Among Art Users in Jimma University Specialized Hospital, Jimma Zone, Oromia Region, South West Ethiopia. Research \& Reviews: A Journal of Immunology, 8(1), pp.14-21.

9. Harahap, Zulpahmi \& Arguni, Eggi \& Rahayujati, Theodola. Determinan ketidakpatuhan terapi antiretroviral pada orang dengan HIV/AIDS dewasa. 2016. Berita Kedokteran Masyarakat. 32. 195. 10.22146/bkm.9825.

10. Notoatmodjo S. Ilmu Perilaku Kesehatan. Jakarta:Rineka Cipta; 2011

11. Adeniyi, O.V., Ajayi, A.I., Ter Goon, D., Owolabi, E.O. Eboh, A. and Lambert, J., 2018. Factors affecting adherence to antiretroviral therapy among pregnant women in the Eastern Cape, South Africa. BMC infectious diseases, 18(1), p.175.

12. Debby, C., Sianturi, S. and Susilo, W. (2019). Factors Related to Compliance of ARV Medication in HIV Patients at RSCM Jakarta. [online] Ejournal.umm.ac.id. Available at: http:/ejournal.umm.ac.id/index.php/keperawatan/ article/view/5886 [Akses 4 Nov. 2019].

13. Hansana, V., Snchaisuriya, P., Durham, J., Sychareun, V., Chaleunvong, K., Boonyaleepun, S., Schelp, F.P. Adherence to Antiretroviral Therapy (ART) among People Living With HIV (PLHIV): a cross-sectional survey to measure in Lao PDR. BMC Public Health. 2013;13(1):1-11
14. Koole, O., Denison, J. A., Menten, J., Tsui, S., WabwireMangen, F., Kwesigabo, G., Bangsberg, D. R. Reasons for missing antiretroviral therapy: Results from a multi-country study in tanzania, uganda, and zambia. 2016.PLoS One, 11(1)

15. Puspasari, D., Wisaksana, R. and Rovina, R. (2018). Gambaran Efek Samping dan Kepatuhan Terapi Antiretroviral pada Pasien HIV di Rumah Sakit Dr. Hasan Sadikin Bandung tahun 2015. Jurnal Sistem Kesehatan, 3(4)

16. Nair, D., Sutarsa, I., Sawitri, A., Kartika Sari, K. 2019. The correlation between demography and clinical status based on WHO staging in MSM HIV patients at Bali Medical Centre. Intisari Sains Medis 10(2). DOI:10.15562/ism.v10i2.202

17. Fonsah J, Njamnshi A, Kouanfack C, Qiu F, Njamnshi D, Tagny C et al. Adherence to Antiretroviral Therapy (ART) in Yaoundé-Cameroon: Association with Opportunistic Infections, Depression, ART Regimen and Side Effects. PLOS ONE. 2017;12(1):e0170893.

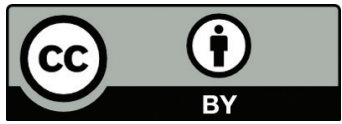

This work is licensed under a Creative Commons Attribution 